\author{
Ангєлов Г.В. \\ доктор философіії, профресор \\ кафедра соціології, фрілософії і права \\ E-mail: sociologia.kafedra@mail.ru \\ Каламан О.Б. \\ кандидат економічних наук, доцент \\ кафедра менеджменту і логістики \\ E-mail: kalaman.olga@ gmail.com \\ Кананихіна О.М. \\ кандидат технічних наук, доцент \\ кафедра біохімії,мікробіології та фізіології харчування \\ E-mail: kelni@ukr.net \\ Соловей A.O. \\ кандидат історичних наук, доцент \\ кафедра соціології, філософрії і права \\ Одеська національна академія харчових технологій \\ вул. Канатна, 112, м. Одеса, Україна, 65039 \\ E-mail: solovanat56@mail.ru
}

\title{
ПРО ПЕРСПЕКТИВНІ НАПРЯМИ РОЗВИТКУ ЕКОНОМІЧНОЇ НАУКИ В ОДЕСЬКІЙ НАЦІОНАЛЬНІЙ АКАДЕМІЇ ХАРЧОВИХ ТЕХНОЛОГІЙ: ІСТОРІЯ І СУЧАСНІСТЬ
}

В статті розглянуто основні етапи становлення економічної науки в Одеській національній академії харчових технологій. Зображено процес відкриття спеціальностей економічного профрілю, виховання висококваліфікованих економічних фахівців, створення економічних фракультетів та створення нових фракультетів. Показано цілі, плани та завдання навчально-наукового Інституту прикладної економіки і менеджменту ім. Г. Е. Вейнштейна, як частини ОНАХТ.

Ключові слова: академія, інститут, економічний напрям, випускники, підготовка фрахівців економічного профрілю, історичний опис.

This work is licensed under a Creative Commons Attribution 4.0 International License http://creativecommons.org/licenses/by/4.0/

Постановка проблеми та її зв'язок з важливими науковими та практичними завданнями. Одеська національна академія харчових технологій, історія якої починається з 1902 р., є сьогодні одним 3 найбільш авторитетних вишів України. Серед структурних підрозділів академії навчально-науковий Інститут прикладної економіки і менеджменту ім. Г. Е. Вейнштейна (ННІПЕіМ ім. Г.Е. Вейнштейна) посідає особливе місце.

Формулювання цілей дослідження. У сучасному суспільстві постійно зростають вимоги до висококваліфікованих фахівців у галузі економіки. Кардинальні зміни економічної ситуації, вступ країни до різних міжнародних організацій, нестабільність ділового клімату, входження на український ринок іноземних фірм, інші економічні та політичні фактори породжують великий попит на працівників економічних спеціальностей. Тому сьогодні підготовка висококваліфікованих фахівців у сфері економіки не тільки не втрачає свого значення, але й набуває особливого сенсу.

Виклад основних результатів та їх обгрунтування. Головним завданням створення та діяль- ності Навчально-наукового інституту прикладної економіки і менеджменту ім. Г. Е. Вейнштейна $\epsilon$ покращення якості навчання, посилення практичної спрямованості підготовки фахівців, підвищення результативності науково-дослідницької роботи, шляхом інтеграції навчального процесу, науки i виробництва, перш за все у сфері прикладної економіки відповідно до профілю діяльності академії. Для його виконання розроблені Концепція, Стратегія і Цільова програма розвитку інституту.

Інституту присвоєне ім'я Григорія Еммануїловича Вейнштейна, наймогутнішого в Російській імперії промисловця-мукомола, голови Всеросійського союзу мукомелів. Г. Е. Вейнштейн народився 13 липня 1860 р. у Херсоні. У 1882 р. Г. Е. Вейнштейн закінчив С.-Петербурзький практично-технологічний інститут і отримав фах інженера-технолога. 31886 р. він був гласним Херсонських повітових і губернських земських зборів і Одеської міської думи, членом Херсонської губернської земської управи.

31894 р. Григорій Еммануїлович призначався членом Херсонського у фабричних справах присутствія, був виборним одеського купецького стану. 
31895 р. Г. Е. Вейнштейн був заступником голови Ради з'їздів мукомелів, членом Обліково-судного комітету Одеської контори Державного банку; членом Одеського біржового товариства; арбітром при Одеській біржі. 31896 р. - мануфактур-радник, купець 1-ї гільдії. Власник торгового дому «Е. М. Вейнштейн і сини», двох будинків і мукомельного млина в Одесі, лісопильного заводу та мукомельного млина у Херсоні.

З 1899 р. він входив до складу Одеського повітового комітету торгівлі та мануфактур, що був однією 3 найстаріших представницьких організацій буржуазії Півдня Російської імперії, до ради Товариства фабрикантів і заводчиків в Одесі, обіймав посаду голови Російсько-англійської торгової палати. Г. Е. Вейнштейн широко займався благодійництвом. У 1916 р. Г. Е. Вейнштейн був членом Ради з’іздіів представників промисловості і торгівлі та аналогічного органу на Півдні країни.

У 1919 р. Г. Е. Вейнштейн емігрував, жив у Парижі, працював інженером на промислових підприємствах, був адміністратором-делегатом палестинських мукомелів, брав участь в нарадах колишніх членів Державної думи та Державної ради у Парижі у 1920 р. Помер 1 січня 1929 р. у Парижі. Похований Григорій Еммануїлович на кладовищі Батіноль у Парижі (Порт-де-Кліші).

Г. Е. Вейнштейн був нагороджений орденами Святого Станіслава 3-го ступеню (1897) і 2-го ступеню (1905), Святої Анни 3-го ступеню (1902), Святого Володимира 4-го ступеню (1914) [1, с. 207].

Григорій Еммануїлович зробив багато, як ініціатор та спонсор створення Одеської школи мукомелів, з відкриттям якої у 1902 р. бере початок Одеська національна академія харчових технологій.

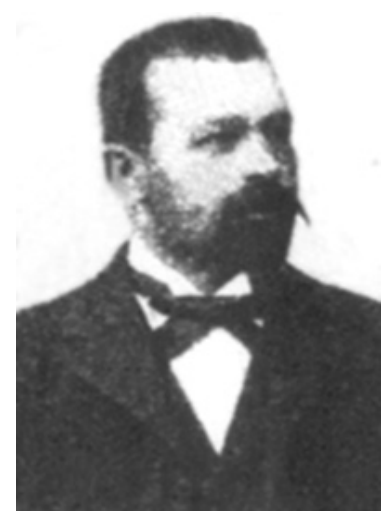

Рис. 1. Засновник Одеської національної академії харчових технологій Григорій Еммануїлович Вейнштейн

Першим директором нового структурного підрозділу академії - Навчально-наукового інституту прикладної економіки і менеджменту ім. Г. Е. Вейнштейна, який був створений згідно наказу ректора 7 вересня 2012 р. став завідувач кафедри економіки промисловості, доктор економічних наук, професор Павлов Олександр Іванович. За період його діяльності до листопада 2013 р. були сформовані основні принципи організаційної діяльності інституту.

Подальший розвиток інституту у період 3 листопада 2013 р. по вересень 2015 р. пов'язаний 3 діяльністю на посаді директора досвідченого керівника - завідувача кафедри менеджменту і логістики, доктора економічних наук, професора Савенка Ігоря Івановича.

3 вересня 2015 р. директором Інституту працює кандидат економічних наук, доцент кафедри менеджменту і логістики Каламан Ольга Борисівна, яка своєю діяльністю ініціює впровадження інноваційних технологій навчання, наукових досліджень та виховної роботи, сприяє активізації роботи підрозділів інституту (рис.2).

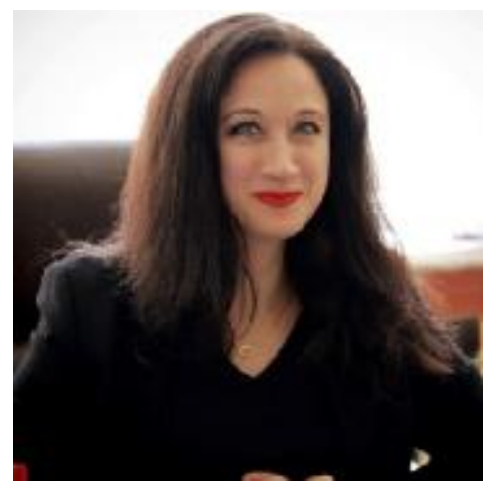

Рис. 2. Директор ННІПЕіМ ім.Г.Е.Вейнштейна Каламан Ольга Борисівна 
Історія підготовки фахівців економічної сфери в ОНАХТ бере свій початок з 1931 р., коли на базі Одеського інституту технології зерна і борошна був створений Одеський механіко-технологічний навчально-виробничий комбінат, у структурі якого відкрили економічний факультет, основу якого складали кафедра фінансово-облікових дисциплін і планово-організаційна кафедра. Факультет в 1935 р. був переданий до складу Московського інституту інженерів харчової промисловості.
31950 р. було відновлено підготовку інженерів-економістів у складі механічного факультету Одеського інституту інженерів борошномельної промисловості та елеваторного господарства.

Важливі зміни відбулися у 1952 р., коли створюється Інженерно-економічний факультет. Деканом факультету був призначений випускник Одеського інституту технології зерна і борошна 1931 р., доцент Микола Хомич Уголик [2, с. 160 ] (рис.3).

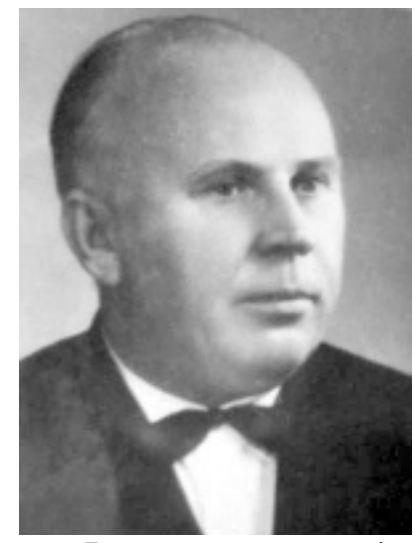

Рис. 3. Перший декан Інженерно-економічного факультету Микола Хомич Уголик

Факультет забезпечував підготовку інженерів економістів за спеціальністю «Економіка та організація промисловості харчових товарів». Підготовку здійснювала кафедра Організації підприємств та економіки промисловості.

У наступні роки деканами працювали: доц. Подзолов Г. Г. (1954-1956 рр.), доц. Уголик М. Х. ( 1956-1968 рр.), доц. Грушевой С. Б. (1968-1975 рр.), доц. Тунтія Г. К. (1975- 2003), доц. Котлік С. В. (2003- 2013).

Суттєві зміни у структурі ОНАХТ відбулися у 2009 р., коли на базі одного факультету економіки, менеджменту і бізнесу було створено два факультети: факультет менеджменту і маркетингу та факультет економіки і бізнесу.

Зміни економічної та політичної ситуації, кон'юнктура ринку, потреби часу вимагали змін в планах підготовки фахівців економічного спрямуван- ня, організації діяльності факультету, що відтворювалося і в змінах назви факультетів. 3 вересня 2011 року затверджена назва факультет економіки, бізнесу i контролю, також факультет менеджменту і маркетингу був реорганізований у факультет менеджменту, маркетингу і логістики.

Навчально-науковий інститут прикладної економіки i менеджменту ім. Г. Е. Вейнштейна створений на базі двох факультетів: економіки, бізнесу і контролю; менеджменту, маркетингу і логістики.

Факультет економіки, бізнесу і контролю, 3 жовтня 2013 року очолює кандидат економічних наук, доцент Купріна Наталія Михайлівна. Деканом факультету менеджменту, маркетингу і логістики 3 2009 р. працює кандидат економічних наук, доцент Агеєва Ірина Миколаївна.

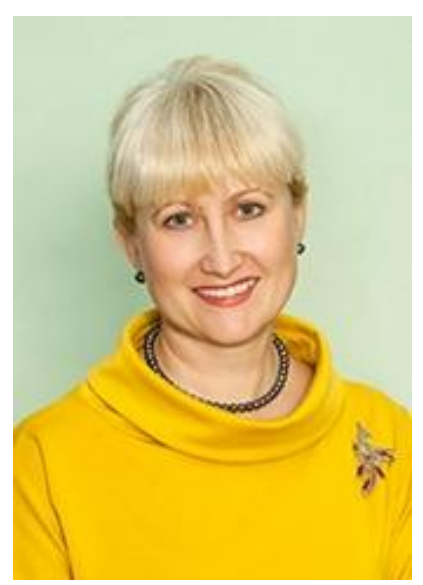

Рис. 4. Декан факультету економіки, бізнесу і контролю доцент Купріна Наталія Михайлівна 


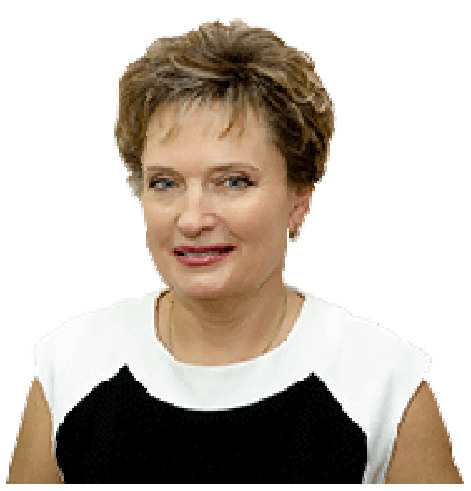

Рис. 5. - Декан факультету менеджменту, маркетингу і логістики доцент Агеєва Ірина Миколаївна

До складу ННІПЕіМ сьогодні входить 8 кафедр, 5 з яких є структурним підрозділом факультету економіки, бізнесу та контролю: обліку і аудиту (зав. каф. доктор економічних наук, професор Немченко Валерій Вікторович), економіки промисловості (зав. каф. доктор економічних наук, професор Павлов Олександр Іванович.), управління бізнесом (зав. каф. доктор економічних наук, доцент Басюркіна Наталія Йосипівна), економічної теорії та фінансовоекономічної безпеки (зав. каф. кандидат політичних наук, доцент Рогатіна Лідія Петрівна), українознавства та лінгводидактики (зав. каф. доктор філологічних наук, професор Віват Ганна Іванівна).

Три кафедри є структурним підрозділом факультету менеджменту, маркетингу і логістики: маркетингу, підприємництва і торгівлі (зав. каф. доктор економічних наук, професор Лагодієнко Володимир Вікторович), менеджменту і логістики (зав. каф. доктор економічних наук, професор Савенко Ігор Іванович), соціології, філософії і права (зав. каф. кандидат історичних наук, заслужений діяч культури України, професор Ангєлов Георгій Віталійович).

В Одеській національній академії харчових технологій підготовка фахівців економічної сфери має давні традиції. Зі стін академії вийшло більше 10500 фахівців цього напрямку, серед яких - більше 300 для різних країн світу.

Сьогодні колектив ННІПЕіМ ім. Г.Е. Вейнштейна складається зі 161 викладача та 1215 студентів. Готуються фахівці ступеню «Бакалавр», та «Магістр» за денною та заочною формами навчання. Всі спеціальності акредитовані за вищим, IV-м рівнем.

3 моменту створення ННІПЕіМ ім. Г. Е. Вейнштейна викладачі кафедр прийняли участь у написанні більше ніж 60 монографій та 20 навчальних посібників.

В інституті відкрита аспірантура за спеціальністю 08.00.04 - «Економіка та управління підприємствами (за видами економічної діяльності)», а також створена можливість навчання в цільовій до- кторантурі, 32012 р. функціонує наукова школа «Забезпечення функціонування і розвитку системи економічної безпеки держави і суб'єктів господарської діяльності» (керівник проф. Павлов О. І.), видаються наукові журнали, розробляється комплексна наукова тема «Соціально-філософські, політикоправові та соціально-психологічні проблеми комунікаційних, управлінських та соціокультурних процесів глобалізованого суспільства» (керівник проф. Ангєлов Г. В.).

За п’ятирічну історію діяльності Навчальнонаукового інституту прикладної економіки і менеджменту ім. Г. Е. Вейнштейна були досягнуті позитивні результати, до яких можна віднести:

- захист 17 кандидатських і 3 докторських дисертацій;

- проведення щорічних Міжнародних науково-практичних конференцій «Економічні та соціальні аспекти розвитку України на початку XXI століття»;

- випуск колективної монографії «Соціоеколого-економічний розвиток агропродовольчої сфери України в сучасних умовах: проблеми та шляхи їх розв'язання»; навчальних посібників «PR як складова ділової культури», «Людина: збагнення простоти в безмежній складності», «У пошуках коду до таємниць особистої чарівливості», «Багатоликість духовної культури людства»;

- організацію наукових видань: «Економіка харчової промисловості»; «Економічна і продовольча безпека України»;

- успішне проведення ліцензування ступеню доктор філософії (PhD) за спеціальностями: 051 «Економіка»; 073 - «Менеджмент»; 076 - «Підприємництво, торгівля та біржова діяльність»;

- започатковано у 2015 р. роботу нової наукової школи «Управління бізнес-структурами України в трансформаційних умовах господарювання», керівник - доктор економічних наук Басюркіна Н. Й.

- активно функціонують студентські наукові гуртки, зокрема, на кафедрі економіки промисловості 
«Економічні процеси трансформаційної економіки», управління бізнесом - Клуб Управління Бізнесом «КУБік», обліку та аудиту «Смарт-бухгалтер», менеджменту і логістики «Менеджмент» та «Клуб юного менеджера», маркетингу, підприємництва і торгівлі «Маркетинг продовольчих товарів», «Маркетинг освітніх послуг», «Маркетолог», «Юний маркетолог»; - функціонування Інституту культури та мистецтв ОНАХТ, ініціатором створення якого стала кафедра Соціології, філософії і права, завданням якого $є$ надання студентам знань $з$ окремих напрямків та проблем культури, формування громадянської свідомості, гідності, високої моральності, культури поведінки, ознайомлення їх $з$ ефективними методами самоосвіти в галузі мистецтва та літератури, етики, естетики, історії, краєзнавства, психології, а також створення лялькового етномузею, відвідувачі якого мають можливість познайомитися 3 національним вбранням народів України;

- роботу філософського клубу «Логос» та психолого-педагогічного семінару-практикуму для аспірантів, молодих викладачів та кураторів академічних груп.

Сьогодні, коли відбувається суттєва трансформація світової економіки та зростає роль фахівців економічної сфери, до перспективних напрямів розвитку інституту можна віднести:

- відкриття Міжнародної наукової школи;

- щорічне видання монографій за науковими напрямами, наукової і навчально-методичної літератури, практикумів;

- проведення на кафедрах наукових конференцій, симпозіумів, круглих столів 3 метою активізації досліджень та обміну науковими знаннями;

- щорічний вступ до аспірантури на ступень доктор філософії (PhD) за спеціальностями: 051 «Економіка»; 073 «Менеджмент»; 076 «Підприємництво, торгівля та біржова діяльність»;

- відкриття аспірантури на ступень вищої освіти - доктор філософії (PhD) за спеціальністю 075 «Маркетинг»;
- захист дисертаційних досліджень на здобуття наукового ступеня доктора економічних наук;

- залучення більшої кількості іноземних учасників до проведення щорічних Міжнародних науково-практичних конференцій «Економічні та соціальні аспекти розвитку України на початку XXI століття»;

- посилення міжнародного співробітництва за напрямами наукових досліджень;

- підвищення якості і практичної направленості магістерських досліджень;

- інтенсифікація наукової роботи з обдарованою молоддю;

- організація діяльності літніх економічних шкіл для аспірантів, студентів та школярів, проведення науково-економічних олімпіад;

- проведення просвітницької діяльності серед населення та профорієнтаційної роботи серед молоді;

- виконання науково-дослідних, експертних, інноваційних, впроваджувальних робіт у галузі економіки (в т.ч. й на основі господарчих договорів);

- надання консультативних послуг щодо методики та технологій фінансового прогнозування; бюджетного планування; інноваційно-інвестиційного проектування; аудиту; маркетингу, з інших питань, що входять до компетенції працівників ННІПЕіМ ім. Г. Е. Вейнштейна.

Висновки та перспективи подальших досліджень. Аналіз тенденцій багатосторонньої діяльності інституту дозволяє впевнено дивитись у майбутнє. Перспективний розвиток Навчально-наукового інституту прикладної економіки і менеджменту ім. Г. Е. Вейнштейна - у безперервному підвищенні кваліфікації професорсько-викладацького складу та співробітників, удосконаленні матеріально-технічної бази, освоєнні передових методологій та методик організації навчально-виховного процесу і проведенні наукових досліджень, забезпеченні співробітництва 3 підприємствами, науковими установами, навчальними закладами України та інших країн світу.

\section{Література}

1. Зінченко О. В. Представники України в Державній раді Російської імперії (1906-1917 рр.): [монографія] / О. В. Зінченко. - Харків: НТМТ, 2013. - 250 с.

2. Кананыхина Е. Н. Одесская национальная академия пищевых технологий / Кананыхина Е. Н., Соловей А. А., Белявская Н. П. ; под ред. проф. Б. В. Егорова. - Одесса: ТЭС, 2012. - 240 с.

Стаття надійшла 03.05.2017

Стаття прийнята до друку 17.05.2017

Доступно в мережі Internet 30.06.2017 
Ангелов Г.В.

доктор философии, профессор кафедра социологии, философии и права

E-mail: sociologia.kafedra@mail.ru

Кананихина Е.H.

кандидат технических наук, доцент кафедра биохимии,микробиологии и физиологии питания

E-mail: k elni@ukr.net
Каламан О.Б.

кандидат экономических наук, доцент кафедра менеджмента и логистики

E-mail: kalaman.olga@ gmail.com

\section{Соловей А.А.}

кандидат исторических наук, доцент кафедра социологии, философиии и права E-mail: solovanat56@mail.ru

Одесская национальная академия пищевых технологий ул. Канатная, 112, г. Одесса, Украина, 65039

\section{О ПЕРСПЕКТИВНЫХ НАПРАВЛЕНИЯХ РАЗВИТИЯ ЭКОНОМИЧЕСКОЙ НАУКИ В ОДЕССКОЙ НАЦИОНАЛЬНОЙ АКАДЕМИИ ПИЩЕВЫХ ТЕХНОЛОГИЙ: ИСТОРИЯ И COBPEMEHHOCTЬ}

Сегодня экономическая наука переживает крайне сложный период в своем развитии. Поэтому на первый план выходит вопрос о подготовке высококвалифицированных, компетентных и адаптированных к реальности специалистов. Так готовят выпускников экономического профиля в Учебнонаучном институте прикладной экономики и менеджмента им.Г.Э.Вейнштейна Одесской национальной академии пищевых технологий.

Важное значение при такой подготовке занимает история создания института. Он был создан на базе двух успешных фракультетов, которые готовили специалистов экономического профиля: экономики, бизнеса и контроля и менеджмента, маркетинга и логистики. Зарождалась такая подготовка как инженерно-экономическая, т.е. более 85 лет ОНАПТ готовит специалистов-экономистов для отраслей пищевой и перерабатывающей промышленности. История формирования такого института сложная, интересная и заслуживает особого внимания. Институт носит имя поистине великого человека для города и академии - Григория Эммануиловича Вейнштейна. Благодаря ему в 1902 году зародилась наша alma mater - Одесская национальная академия пищевых технологий.

Сегодня в составе Учебно-научного института 8 кафедр, шесть из которых экономической направленности. Возглавляют кафедры известные ученые - профессора Павлов А.И., Савенко И.И., Немченко В.В., Лагодиенко В.В., Басюркина Н.Й., Рогатина Л.П., Виват А.И., Ангелов Г.В.

Учебно-научный институт прикладной экономики и менеджмента им.Г.Э.Вейнштейна сегодня это мощный центр развития экономической науки в бурной реальности государственных реформаций.

Ключевые слова: академия, институт, экономическое направление, выпускники, подготовка специалистов экономического профиля, историческое описание.

Angelov G.

Ph.D., Professor

Department of the Sociology, Philosophy and Law E-mail: sociologia.kafedra@mail.ru

Kananykhina 0.

Ph.D., Associate Professor

Department of Biochemistry, Microbiology and

Physiology of Food

E-mail: $\underline{\text { elni@ukr.net }}$
Kalaman 0.

Ph.D., Associate Professor

Department of Management and Logistics E-mail: kalaman.olga@ gmail.com

Solovei A.

Ph.D., Associate Professor

Department of the Sociology, Philosophy and Lan

E-mail: solovanat56@mail.ru

Odessa National Academy of Food Technologies

Kanatna Str., 112, Odessa, Ukraine, 65039

\section{ABOUT THE PERSPECTIVE DIRECTIONS OF DEVELOPMENT OF ECONOMIC SCIENCE IN ODESSA NATIONAL ACADEMY OF FOOD TECHNOLOGIES: HISTORY AND THE PRESENT}

Today, economic science is experiencing an extremely difficult period in its development. Therefore, the question of preparing highly qualified, competent and adapted to reality specialists comes to the fore. 
This is how graduates of the economic profile are trained in the Teaching and Research Institute of Applied Economics and Management named after G.Veynshtein of Odessa National Academy of Food Technologies.

The history of the institution is important in this preparation. It was created on the basis of two successful faculties that trained economics specialists: economics, business and control and management, marketing and logistics. Such training appeared as engineering and economic one, that is, for more than 85 years, ONAFT has been training economists for the food and processing industries. The history of the formation of such institution is complex, interesting and deserves special attention. The Institute bears the name of a truly great man for the city and academy - Grigory Veynshtein. Thanks to him in 1902 our alma mater, Odessa National Academy of Food Technologies, was born.

Today, there are 8 chairs in the teaching and research institute, six of which are economically oriented. The chairs are headed by the famous scientists - professors Pavlov A., Savenko I., Nemchenko V., Lagodienko V., Basiurkina N., Rogatina L., Vivat A., Angelov G.

Teaching and Research Institute of Applied Economics and Management named after G.Veynshtein today is a powerful center of the development of economic science in the turbulent reality of state reforms.

Keywords: academy, institute, economic direction, graduates, training of specialists of an economic profile, historical description.

\section{References} kiv. NTMT.

1. Zinchenko O. V. (2013). Predstavnyky Ukrainy v Derzhavnii radi Rosiiskoi imperii (1906-1917 rr.). Khar-

2. Kananykhina E. N., Solovei A. A., Beliavskaia N. P., Ehorov B. V. (2012). Odesskaia natsyonalnaia akademyia pyshchevykh tekhnolohyi. Odessa. TЭS. 


\section{ДЛЯ НОТАТОК}

